Available online on 15.10 .2020 at http://jddtonline.info
Open Access to Pharmaceutical and Medical Research
unrestricted non-commercial use, provided the original work is properly cited

Open 1 Access

Review Article

\title{
Creams: A Review on Classification, Preparation Methods, Evaluation and its Applications
}

\section{Chauhan Lalita*, Gupta Shalini}

School of Pharmacy and Emerging Sciences, Baddi University of Emerging Sciences and Technology, Village Makhnumajra Baddi Dis trict Solan, Tehsil Nalagarh, H.P-173205

\begin{abstract}
Creams are considered an important part of cosmetic product as topical preparations from time immemorial due to their ease of application to the skin and also their removal. From cosmetic purposes, Pharmaceutical creams have a variety of applications such as cleansing, beautifying, altering appearance, moisturizing etc. to skin protection against bacterial, fungal infections as well as healing cuts, burns, wounds on the skin These semi solid preparations are safe to use by the public and society. The human skin is easily vulnerable to injury but it has the capability to heal on its own. However, the natural healing process can take time and there is also risk of infection especially in the early stages of injury. In such cases, medicated creams can be applied to the site of injury to speed up the healing process as well as protect the wound from infection. In this review, we have focused on the use of topical drug delivery system i.e. pharmaceutical creams for wound healing with detailed discussion relating to the wound healing process, suitable methods of preparation of creams, their classification based on their function, their advantages and disadvantages, characteristics and the various types of creams, ingredients used in the formulation of creams and their various evaluation parameters.
\end{abstract}

Keywords: Creams, Skin, Topical drug delivery system, Wound healing

Article Info: Received 13 Aug 2020; Review Completed 10 Sep 2020; Accepted 22 Sep 2020; Available online 15 Oct 2020

Cite this article as:

Chauhan L, Gupta S, Creams: A Review on Classification, Preparation Methods, Evaluation and its Applications, Journal of Drug Delivery and Therapeutics. 2020; 10(5-s):281-289 http://dx.doi.org/10.22270/jddt.v10i5-s.4430

*Address for Correspondence:

Lalita Chauhan, Assistant Professor (Pharmaceutics), School of Pharmacy and Emerging Sciences, Baddi University of Emerging Sciences and Technology, Village Makhnumajra Baddi District Solan, Tehsil Nalagarh, H.P-173205

\section{INTRODUCTION}

The word 'Cosmetic' derived from a Greek word 'kosmesticos' that means to adorn. From that time any materials used to beautification or promoting appearance is known as cosmetic.[1] The word "cosmetics" actually stems from its use in Ancient Rome. They were typically produced by female slaves known as "cosmetae" which is where the word "cosmetics" stemmed from. Cosmetics are used to enhance appearance. Makeup has been around for many centuries. The first known people who used cosmetics to enhance their beauty were the Egyptians. Makeup those days was just simple eye coloring or some material for the body. Now-a-days makeup plays an important role for both men and women. The importance of cosmetics has increased as many people want to stay young and attractive. Cosmetics are readily available today in the form of creams, lipstick, perfumes, eye shadows, nail polishes, hair sprays etc. Other cosmetics like face powder give glow to the skin after applying the base cream. Then we have lipsticks, which are applied by many women of all ages. They are made from wax and cocoa butter in the desired amount. Cosmetics like creams, gels, and colognes are used on a daily basis by both women and men. Creams act as a cleanser for the face in many circumstances. More recently anti-ageing creams have been manufactured which can retain younger looking skin for many years. The best cleansing agents are cleansing cream, soap and water. Cosmetic creams serve as a skin food for hard, dry and chapped skin. It mainly lubricates, softens and removes unwanted dirt from the skin. Some popular fat creams that are used include Vaseline and Lanolin. Dry creams are used in the manufacture of soap and gelatin which is used as a base for the skin. Hair care has become one of the fastest developing markets in the beauty industry. Many young men turn to oils and gels to maintain and style their hair. Products like hair gels, oils, and lotions have been introduced in the market to help protect hair fall and dandruff. Some professions, like the show business industry, focus on the importance of the outer appearance. Many personalities and artists have utilized makeup to beat the harsh lights and the glare of camera flashes. They very well know the importance of their looks and maintain them by using a variety of cosmetics. Recent research has shown that 
makeup helps in protection from harmful rays of the sun. Many beauty products manufacturers have utilized the needs of people to protect themselves and their skin from the rays of the sun. Many beauty products manufacturers have utilized the needs of people to protect themselves and their skin from the rays of the sun. The Importance of Cosmetics Today Cosmetics help to enhance our appearance and make us feel more confident. With more cosmetics on the market today than ever before, it becomes obvious to us that they play a great role in our everyday life.

\section{TOPICAL DRUG DELIVERY}

Over the last decades the treatment of illness have been accomplished by administrating drugs to human body via various roots namely oral, sublingual, rectal, parental ,topical ,inhalation etc. Topical delivery can be defined as the application of a drug containing formulation to the skin to directly treat cutaneous disorder or the cutaneous manifestations of a general disease (eg. psoriasis) with the intent of containing the pharmacological or the effect of drug to the surface of the skin or within the skin semisolid formulations in all their diversity dominate the system for topical delivery, but foams, spray, medicated powders, solutions and even medicated adhesive systems are in use.[2]

\section{Advantages of topical drug delivery system}

- Avoidance of first pass metabolism.

- Convenient and easy to apply.

- $\quad$ Avoid of risk.

- Inconveniences of intravenous therapy and of the varied conditions of absorption like $\mathrm{Ph}$ changes presence of enzymes gastric emptying time etc.
- Achievement of efficacy with lower total daily dosage of drug by continuous drug input.

- Avoid fluctuation of drug levels inter and intra patent variations.

- $\quad$ Skin irritation or dermatitis may occur due to the drug or excipients.

- Most drugs have a high molecular weight and are poorly lipid soluble, so are not absorbed via skin or mucous membranes.

- Very slow absorption.

- It can be used only for those drugs which need very small plasma concentration for action.

- $\quad$ Can be used only for drugs which require very small plasma concentration for action

- Possibility of allergic reactions.

- Drugs of larger particle size not easy to absorb through the skin.[3]

\section{PHYSIOLOGY OF HUMAN SKIN}

\section{Epidermis}

The epidermis is the most superficial layer of the skin and is composed of stratified keratinised squamous epithelium, which varies in thickness in different parts of the body. It is thickest on the palms of the hands and soles of the feet. There are no blood vessels or nerve endings in the epidermis, but its deeper layers are bathed in interstitial fluid from the dermis, which provides oxygen and nutrients, and drains away as lymph.

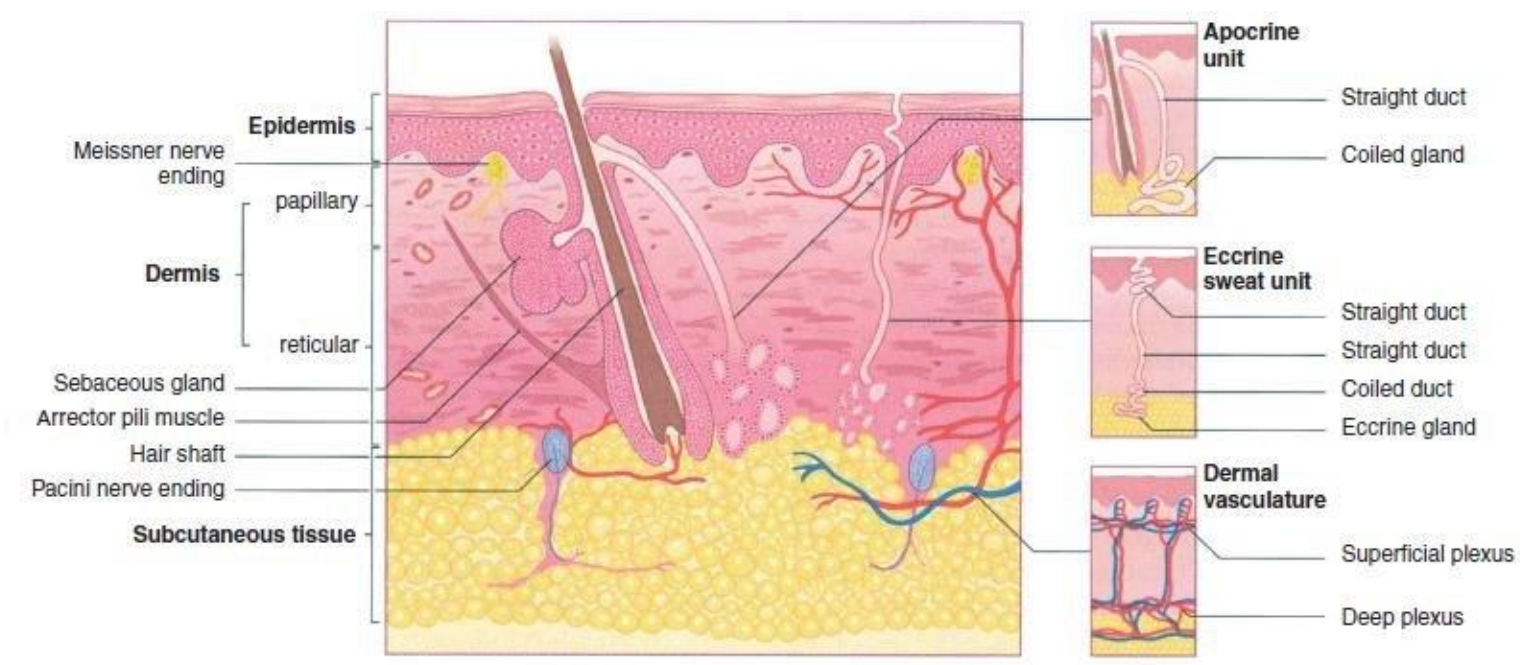

Figure 1: Cross-Section of Skin[4]

\section{Dermis}

The dermis is tough and elastic. It is formed from connective tissue and the matrix contains collagen fibres interlaced with elastic fibres. Rupture of elastic fibres occurs when the skin is overstretched, resulting in permanent striae, or stretch marks, that may be found in pregnancy and obesity. Collagen fibres bind water and give the skin its tensile strength, but as this ability declines with age, wrinkles develop. Fibroblasts, macrophages and mast cells are the main cells found in the dermis. Underlying its deepest layer there is areolar tissue and varying amounts of adipose (fat) tissue.

\section{Subcutaneous gland}

These consist of secretory epithelial cells derived from the same tissue as the hair follicles. They secrete an oily substance, sebum, into the hair follicles and are present in the skin of all parts of the body except the palms of the hands and the soles of the feet. They are most numerous in the skin of the scalp, face, axillae and groins. In regions of transition from one 
type of superficial epithelium to another, such as lips, eyelids, nipple, labia minora and glans penis, there are sebaceous glands that are independent of hair follicles, secreting sebum directly onto the surface.[5]

\section{FUNCTIONS OF SKIN}

Skin performs the following functions:

a) Protection: An anatomical barrier from pathogens and damage between the internal and external environment in bodily defence, Langerhans cells in the skin are part of the adaptive immune system.

b) Sensation: Contains a variety of nerve endings that react to heat and cold, touch, pressure, vibration, and tissue injury, see somato sensory system and haptics.

c) Heat regulation: The skin contains a blood supply far greater than its requirements which allows precise control of energy loss by radiation, convection and conduction. Dilated blood vessels increase perfusion and heat loss, while constricted vessels greatly reduce cutaneous blood flow and conserve heat.

d) Control of evaporation: The skin provides a relatively dry and semi-impermeable barrier to fluid loss. Loss of this function contributes to the massive fluid loss in burns.

e) Aesthetics and communication: Others see our skin and can assess our mood, physical state and attractiveness.

f) Storage and synthesis: Acts as a storage centre for lipids and water, as well as a means of synthesis of vitamin D by action of UV on certain parts of the skin.

g) Water resistance: The skin acts as a water resistant barrier so essential nutrients aren't washed out of the body.

\section{DISEASES OF SKIN}

\section{a) Vitiligo}

Vitiligo is a condition in which areas of skin lose their normal pigment and so become white. It is common, and affects about $1 \%$ of the world's population. The pigment that gives your skin its normal colour is melanin, which is made by cells known as melanocytes.

\section{b) Scabies}

Scabies is a common and very itchy skin condition caused by human scabies mites. It can affect people of any age but is most common in the young and the elderly. The mites that cause scabies are tiny parasites, smaller than a pinhead. The rash of scabies is a mixture of scratch marks and red scaly areas; later it can become infected and develop small pus spots.

\section{c) Rosacea}

Rosacea is a common rash, found on the central part of the face, usually of a middle aged person. A tendency to flush easily is followed by persistent redness on the cheeks, chin, forehead and nose. The cause of rosacea is not fully understood, but many think that the defect lies in the blood vessels in the skin of the face, which dilate too easily.

\section{d) Psoriasis}

Psoriasis is a common skin problem affecting about $2 \%$ of the population. It occurs equally in men and women, at any age, and tends to come and go unpredictably. It is not infectious, and does not scar the skin. The skin is a complex organ made up of several different layers.

\section{e) Melanoma}

Cutaneous malignant melanoma is a cancer of the pigment cells of the skin. If it is treated early, the outlook is usually good. It is not contagious. The word 'melanoma' comes from the Greek word 'melas', meaning black. Melanin is the dark pigment that gives the skin its natural colour.

\section{f) Eczema (Atopic Eczema)}

Atopic eczema is an inflammatory condition of the skin. Atopic is the term used to describe conditions such as eczema, asthma, seasonal rhinitis and hay fever, which often have a genetic basis. Eczema is the term used to describe changes in the upper layer of the skin that include redness, blistering, oozing, crusting, scaling, thickening and sometimes pigmentation.

\section{CREAMS}

Creams are the topical preparations which can be applied on the skin. Creams are defined as "viscous liquid or semi-solid emulsions of either the oil-in-water or water-in-oil type" dosage forms which consistency varies by oil and water.[6] Creams are used for cosmetic purposes such as cleansing, beautifying, improving appearances, protective or for therapeutic function. These topical formulations are used for the localized effect for the delivery of the drug into the underlying layer of the skin or the mucous membrane. These products are designed to be used topically for the better site specific delivery of the drug into the skin for skin disorders. [7]

Creams are considered as a pharmaceutical product as they are prepared based on techniques developed in the pharmaceutical industry; unmedicated and medicated creams are highly used for the treatment of various skin conditions or dermatoses. Creams can be ayurvedic, herbal or allopathic which are used by people according to their needs for their skin conditions. They contain one or more drugs substances dissolved or dispersed in a suitable base. Creams may be classified as $\mathrm{o} / \mathrm{w}$ or w/o type of emulsion on the basis of phases. The term 'cream' has been traditionally applied to semisolid formulated as either water-in-oil (e.g.: cold cream) or oil-in-water (e.g.: vanishing cream).[8]

\section{TYPES OF SKIN CREAMS}

They are divided into two types:

Oil-in-Water $(\mathbf{0} / \mathbf{W})$ creams which are composed of small droplets of oil dispersed in a continuous phase, and an emulsion in which the oil is dispersed as droplets throughout the aqueous phase is termed an oil-in-water $(0 / W)$ emulsion.

Water-in-Oil (W/0) creams which are composed of small droplets of water dispersed in a continuous oily phase. When water is the dispersed phase and an oil the dispersion medium, the emulsion is of the water-in-oil (W/0) type.[9-11]

\section{CLASSIFICATION OF CREAMS}

All the skin creams can be classified on different basis:

1. According to function, e.g. cleansing, foundation, massage, etc.

2. According to characteristics properties, e.g. cold creams, vanishing creams, etc.

3. According to the nature or type of emulsion.

Types of creams according to function, characteristic properties and type of emulsion: 
1. Make-up cream (o/w emulsion): a) Vanishing creams. b) Foundation creams.

2. Cleansing cream, Cleansing milk, Cleansing lotion (w/o emulsion)

3. Winter cream (w/o emulsion): a) Cold cream or moisturizing creams.

4. All-purpose cream and general creams.

5. Night cream and massage creams.

6. Skin protective cream.

7. Hand and body creams.

\section{Make-up cream-}

These are mainly o/w type of emulsion. It is cream-based product which leaves a smooth hydrated finish (either stain matte or luminous) on the skin. It nourishes skin andis basically sweat-resistant and creates a dewy sheen.

- Vanishing creams: They are called vanishing creams because they seem to disappear when rubbed onto the skin. These formulations are based on stearic acid. After application, the cream leaves a dry but tacky residual film which also has a drying effect on the skin. Because of this reason, these are used particularly in hot climates which cause perspiration on the skin.

- $\quad$ Foundation creams: These cream serve as a foundation base for make-up. It acts as an adherent base for application of make-up powders. They provide emollient action and a protective action against environment to the skin which is neither too greasy nor too dry. It is multicoloured make up applied on the face to create an even, uniform colour similar to the complexion, to cover flaws and to change the skin tones.

\section{Cleansing creams}

These creams are used for body cleaning purposes and it is used for personal hygiene and beautification which is important for cosmetics. Cleansing creams or lotions can be used for the removal of make-up, surface grim, oil mainly from the face and neck.

\section{Winter creams}

These are w/o type of formulation and in this formulation oil content will be more than water content. These creams are mainly used for chapped and dry skin. Cold cream: It is known as moisturizer or moisturizing cream. Cold cream must have an emollient action. It should produce a cooling sensation in use and the oil film on the skin should be nonocclusive.

\section{All purpose creams and general creams}

These creams are used more nowadays than before. These creams are somewhat oily but non-greasy type and can spread on the skin easily. This can also be used as a night creams, nourishing creams, protective creams for prevention or alleviation of sunburns or for the treatment of roughened skin areas.

\section{Night cream or massage creams}

These creams are mainly used for the nourishing the skin or as a treatment to dry skin. Creams which are generally applied on skin and left for few or several hours over night are mainly known as night creams. Creams which acts as an emollient by rubbing the cream on the skin with massage is known as massage cream.

\section{Skin protective creams}

These creams are smooth, thick bodied creams formulated to provide an invisible, uniform protective film barrier to the skin. It helps to maintain the barrier between the skin and contaminants that may irritate the skin (contact dermatitis and occupational dermatitis). Strengthens the natural properties of the skin and maintains the balance of normal to combination skin.

\section{Hand and body creams}

Hands are one of the first places to show signs of aging. We tend to wash our hand several times a day, stripping off moisture. Applying cream softens and protects the skin and it keeps the skin looks younger. Since the skin on our palms and fingers needs oil to stay supple and to prevent it from chapping and cracking, it is sensible to use hand creams that puts plenty of oil back in. It is used on the hands more than other parts of the body.[12-15]

\section{GENERAL INGREDIENTS USED IN SKIN CREAMS}

The raw materials which are used in a manufacturing of skin creams include:

Water: This is the most important and widely used raw material in any cream formulation. These are the cheapest and easily available. In skin creams, water is used as solvent to dissolve other ingredients of creams. Water, which is free of any toxins, pollutants, microbes, etc. is used in preparation of creams. Water can also form emulsions, it depends upon how much quantity of water is used in the formulation and sometimes referred to as oil-in-water emulsions and sometimes water-in-oil emulsions depending upon the quantities of oil phase and water phase used.[16]

$>$ Oil, fates and waxes: Oil, fats and waxes and derivatives there form comprise an essential portion of creams. Waxes act as an emulsifier, fats act as a thickener and oil act as a perfuming agent, preservative, etc. according to its function .Oil may be two types' mineral and glyceride

$>$ Mineral oil: Mineral oil consists of hydrocarbons derived from petroleum oil .Mineral oil is clear, odorless, and heavily refined oil and it is widely used in cosmetics. Mineral oil rarely causes allergic reactions and it cannot become solid and clog pores of the skin. It is light weight and inexpensive, it helps to reduce water loss from the body and keeps body moisturized. A number of mineral oils are used in cream formulation.

Examples:

- Light liquid paraffin

- Heavy liquid paraffin

- $\quad$ Liquid petroleum

> Glyceride oil: Glyceride oil is mostly vegetable oils. Examples of glyceride oils are almond oil, arachis oil, castor oil, coconut oil, olive oil etc.

$>$ Vegetable oil: Form a barrier on the surface of the skin and slow down the loss of water, helping to maintain plumpness of skin. Vegetable oils may also be used to increase the thickness of the lipid or oil portion of cream or personal care products.E.g. Almond oil, germ oil, avocado oil, sunflower oil etc.[17] Waxes: Which are used in preparation of cream includes beeswax, carnauba wax, ceresin, spermaceti, etc. Waxes are used in cosmetics because it helps to keep an emulsion from separation of oil and liquid components. These waxes 
also increase the thickness of the lipid portion and sticks on the surface of the skin.

$>$ Fats: Different types of fats are used in the preparation of creams. These materials can be obtained from animals, plants or mineral origin. Glyceride oils and fats may be of animals or vegetable origin. They consist of combinations of higher fatty acids and glycerin. When saponified they form soap, or fatty acid and glycerin, depending upon process used. The most common of these fatty acid are lauric, margaric, plamitic, stearic, saturated group. Oleic acid is liquid and most popular unsaturated fatty acid. More specially the oil most commonly used in other cosmetics are olive oil, almond oil, seasame oil, peanut oil, coca butter fat, mutton tallow, lard and beef stearine.[18]

$>$ Lanolin: It is derived from wool fat of a sheep. Lanolin are of two types- the hydrous lanolin contains between $25 \%-30 \%$ water. Anhydrous lanolin has point of $38^{\circ} \mathrm{C}$ $42^{\circ} \mathrm{C}$ and has a slight odour. These ingredients act as a lubricant on the skin surface, which gives the skin soft and smooth appearance. Lanolin helps to form emulsion and blends well with other substances used in cosmetic and personal care products.

$>$ Colours: Before the development of the modern technology, colours primarily came from substances found in nature such as turmeric, saffron, indigo, etc. After the 19th century, colours were made in the laboratory and were found to be much more stable with greater colouring intensity. They also could be produced without using plants harvested in the wild.[19]

$>$ Emollients: Emollients, also commonly referred to as moisturizers, are products that help to soften skin or to treat skin that has become dry. Most emollients are forms of oil or grease, such as mineral oil, squalene, and lanolin They work by increasing the ability of the skin to hold water, providing the skin with a layer of oil to prevent water loss, and lubricating the skin.[20]

$>$ Humectants: These are important multi-functional ingredients found in most skin care formulations. Humectants are hydroscopic organic compounds. These are the materials that can absorb or retain moisture. These has many benefits such as moisturization, exfoliation, etc. Examples of humectant are glycerin, Hydroxyethyl urea, betaine, sodium PCA, Sodium-LLactate, etc.[21]

$>$ Perfumes: Perfume is a substance that imparts a scent or order, including a sweet and pleasant smell. Examples of natural perfumes used in creams are-

- White Blossoms:

- $\quad$ Rosy Dreams

- $\quad$ Orange Blossom[22]

> Vitamins: Vitamins plays an important role in maintaining the physiological function of whole body and the skin. Vitamin A, B, C, E etc. are generally used in formulation of the creams.

$>$ Preservatives: The use of preservatives in cosmetics is essential to prevent alteration caused by microorganism and contamination during formulation, shipment, storage and consumer use. Antioxidants can also be used to protect alteration caused by exposure to oxygen. Synthetic preservatives when used in low concentration 3 . effectively preserve the products.[23]

\section{WOUND AND WOUND HEALING PROCESS}

Wounds may be defined as a loss or breaking of cellular and anatomic or functional continuity of the deep skin tissue or the living tissues. Wounds may be produced by physical, chemical, thermal, viral, microbial, violence or the immunological trauma to the surface of the skin.[24-28] Wounds not only affect the patient physically and emotionally but can also significantly cost them and the scars may remain for the lifetime of the patient. Wounds are generally termed as the physical injury that causes opening and breaking of the skin. Wounds can be classified mainly on the basis of mode of infliction and causative agent as:[29-30]

1) Closed wound: contusion, closed fracture, etc.

2) Open wound

a) Sharp cut.

b) Laceration.

c) Abrasion.

d) Avulsion.

e) Crush wound.

f) Punctured wound.

g) Bite wound.

h) Burn wound

Wound healing is a process of cell contraction, movement, readhesion after injury or trauma of the skin. Wound healing involves platelet aggregation, blood clotting, formation of fibrin, inflammatory response to damage, alteration in the ground substances, angiogenesis and re- epithilization.[31-32] Healing process cannot be complete until the disrupted surface are vigorously knit by collagen and finally terminated by scars formation.[33-34] The process of wound healing may be hampered by the presence of free radicals which will damage the surrounding skin tissues. And the process of wound healing is influenced by several factors such as infections, nutrition, drugs and hormones, type and the sites of the wound and certain disease conditions.[35] In India, since centuries people are using natural products obtained from plant and animal for treatment of wounds which was taught in a popular form of Indian medicine know as Ayurveda.[36] Natural products have been used since centuries in different parts of world; natural products are becoming as important as alternative medicine because of their comparatively lesser side effects. Due to these reasons, natural/traditional medicine are investigated scientifically for the betterment of human health. These are used directly as in crude or raw form of drug for the treatment of chronic diseases.[37-39]

\section{AYURVEDIC MEDICINES FOR WOUND HEALING}

1. Aloe Vera (A. barbadensis): It is one of the important herbs in Ayurveda. It is having wide range of uses in skin conditions such as burns, psoriasis, cold sores, etc. It can also be for fever, itching, inflammation. [40-41]

2. Peppermint (Mentha piperita): It is a popular herb and it is used in numerous forms. Peppermint oil when applied on the skin provides a cooling sensation. It is used in aromatherapy, bath preparation, mouth washes, toothpaste and topical preparations. It is used to calm pruritus, relieve irritation and inflammation and wound healing.[42-43]

3. Turmeric (Curcuma longa): In India, turmeric is used as spices as well as a colouring agent. It is having various medicinal properties as anti-cancer, antidiabetic, 
antioxidant, anti-inflammatory, antibacterial, antiviral, wound healing, etc.[44-45]

4. Jatropacurcas: It is known for various medicinal properties. It is having anti-microbial, anti-cancer, anti HIV , anti-bacterial, wound healing, etc. [46]

5. Honey: Honey has been used since ancient times as a traditional medicine. Honey is having antioxidant, antitumor, anti-inflammatory, anti-microbial and cardiovascular potentiating agent. It is also used as a wound dressing and wound healing agent. Honey has been used to treat adult and neonatal postoperative infections, burns, necrotizing fasciitis, infected and nonhealing wounds and ulcers, boils, pilonidal sinus, venous ulcer and diabetic foot ulcers. [47-48]

6. Marigold (Calendula officinalis): It is a short lived aromatic herbaceous perennial plant. It is a flower/plant which that has been used for centuries for ornamental purpose, cosmetic and medicinal purpose. Calendula is one of the top herbs and can be taken orally, it is one of the most powerful antioxidant and it is one of the strongest antiviral herbs. It is having anti-inflammatory, calms muscle spasm, heals ulcers, wounds, and hemorrhoids, aids menstruation, contains antimicrobial and antiviral components, improves oral health.[49-50]

7. Ghee: The butter which is obtained from the cow milk has been claimed to have many medicinal properties like it is cooling in energy, rejuvenating, bestows luster and beauty, enhances memory and stamina, increases the intellect, and promotes longevity. It is having antimicrobial, immune stimulant, antioxidant and hepatoprotective activity. The process of wound healing by cow ghee is faster than antibiotics. Cow ghee contains several saturated and unsaturated fatty acids which are capable of taking part in metabolic processes involved in healing of any wounds.[51-52]

Table 2: Examples of some plants currently investigated for wound-healing applications

\begin{tabular}{|c|c|c|c|c|}
\hline Herb & Main Constituents & $\begin{array}{l}\text { Physical Forms and } \\
\text { Administration Routes }\end{array}$ & $\begin{array}{l}\text { Laboratorial and } \\
\text { Clinical Evidence }\end{array}$ & Ref \\
\hline Aloe Vera & $\begin{array}{l}\text { Soluble sugars, nonstarch } \\
\text { polysaccharides, lignin, } \\
\text { polysaccharides, glycoproteins, } \\
\text { and antiseptic agents }\end{array}$ & $\begin{array}{l}\text { Forms: solutions, } \\
\text { creams ,mucilage, gels, } \\
\text { and dressing Routes: } \\
\text { topical and oral }\end{array}$ & $\begin{array}{l}\text { Anti-inflammatory and } \\
\text { antimicrobial activity; } \\
\text { stimulate cell } \\
\text { proliferation }\end{array}$ & [53-57] \\
\hline $\begin{array}{l}\text { Hippophaerhamnoides } \\
\text { (sea buckthorn) }\end{array}$ & $\begin{array}{l}\text { Flavonoids (e.g., quercetin, } \\
\text { isorhamnetin), carotenoids } \\
\text { (e.g., alpha, beta-carotene, } \\
\text { lycopene), vitamins(C,E,K), } \\
\text { tannins, organic acids, } \\
\text { triterpenes, glycerides of } \\
\text { palmitic, stearic, oleic acids and, } \\
\text { amino acids }\end{array}$ & $\begin{array}{l}\text { Forms : aqueous leaf } \\
\text { extract, seed oil } \\
\text { Routes :topical and oral }\end{array}$ & $\begin{array}{l}\text { Antioxidant and anti- } \\
\text { inflammatory activities; } \\
\text { stimulate the healing } \\
\text { process; improve wound } \\
\text { contraction and } \\
\text { epithelialization; } \\
\text { increase the } \\
\text { hydroxyproline and } \\
\text { protein content in the } \\
\text { wound }\end{array}$ & [58-59] \\
\hline Angelica sinensis & $\begin{array}{l}\text { Essential oils and water-soluble } \\
\text { ingredients; ferulic acid is the } \\
\text { main active constituent }\end{array}$ & $\begin{array}{l}\text { Forms: ethanol extract, } \\
\text { ferulic acid dissolved in } \\
\text { DMSO } \\
\text { Routes: n.a (in vitro } \\
\text { tests) }\end{array}$ & $\begin{array}{l}\text { Stimulate the } \\
\text { proliferation of human } \\
\text { skin fibroblasts, the } \\
\text { secretion of collagen }\end{array}$ & {$[60]$} \\
\hline $\begin{array}{l}\text { Catharanthus roseus } \\
\text { (Vinca rosea }\end{array}$ & $\begin{array}{l}\text { Contain two major classes of } \\
\text { active compounds: alkaloids } \\
\text { (e.g., vincamine) and tannins }\end{array}$ & $\begin{array}{l}\text { Forms:leaf ethanol } \\
\text { extract } \\
\text { Routes: topical }\end{array}$ & $\begin{array}{l}\text { Antimicrobial activity } \\
\text { against Pseudomonas } \\
\text { aeruginosa and } \\
\text { Staphylococcus aureus; } \\
\text { increase wound } \\
\text { strength, } \\
\text { epithelialization, and } \\
\text { wound contraction }\end{array}$ & [61-62] \\
\hline $\begin{array}{l}\text { Calendula officinalis } \\
\text { (marigold) }\end{array}$ & Triterpenoids and flavonoids & $\begin{array}{l}\text { Forms:gels, aqueous } \\
\text { extracts, hexane, and } \\
\text { ethanolic extracts } \\
\text { dissolved in DMSO } \\
\text { Routes: Topical }\end{array}$ & $\begin{array}{l}\text { Anti-inflammatory and } \\
\text { antibacterial activities; } \\
\text { stimulate the } \\
\text { proliferation and } \\
\text { migration of fibroblasts } \\
\text { in vitro }\end{array}$ & {$[63]$} \\
\hline
\end{tabular}

\section{ALTERNATIVE MEDICINES/CREAMS FOR WOUND HEALING}

1. Soframycin: The Soframycin skin creams is manufactured as $1 \% \mathrm{w} / \mathrm{w}$ as per IP which has Framycetinsulphate as the main component. Soframycin skin cream are used in curing wounds, furunculosis, cuts, burns, ulcers, lice, impetigo, otitis externa, scabies, sycosis barbae, etc. [64]

2. Neosprine: It is made up of three antibiotics that are neomycin sulphate, polymyxin B sulphate and bacitracin zinc. The topical ointment can be used to treat certain skin infections in burns, minor cuts, and 
wounds. These antibiotics works by killing bacteria that causes these infections.

3. Silver Nitrate: It is a prescription topical solution used in treating wounds and burns on the skin as an antiinfective agent, antiseptic and caustic. There is little literature about the adverse effect of silver nitrate. Silver nitrate can potentially be used as a cauterizing or sclerosing agent.[67] Silver Sulphadiazine: This medication is used along with other treatment to help prevent and treat wound infections in patients with serious burns. Silver sulphadiazine works by stopping the growth of bacteria that may infect an open wound. This helps to decrease the risk of the bacteria spreading to surrounding skin, or to the blood where it can cause a serious blood infection (sepsis). Silver sulphadiazine belongs to a class of drugs known as sulfa antibiotics. Silver sulphadiazine cream is used to prevent and treat wound infections in patients with second- and third degree burns. Silver sulphadiazine must not be used on premature babies or on newborns during the first 2 months of life because of the risk of serious side effects.[65]

4. Cetrimide: It is an antiseptic which is a mixture of different quaternary ammonium salts including cetrimonium bromide. It was first discovered and developed by ICI and introduced under the brand name Cetavlon. It is used as a $1-3 \%$ solution for cleaning roadside accident wounds.

5. Betadine: It is having an active ingredient as Povidone Iodine USP $10 \% \mathrm{w} / \mathrm{w}$ (available iodine 1\%). Povidone iodine is bactericidal against gram-positive and gram negative bacteria. It is a broad-spectrum antiseptic for the topical treatment or prevention of infection in minor cuts and abrasions, minor surgical procedures and small area of burns, treatment of mycotic and bacterial skin infections.[64]

\section{RELEVANT METHODS OF PREPARATION OF CREAMS FOR WOUND-HEALING:}

\section{- Preparation of $0 / w$ emulsion cream}

The oil soluble components and the emulsifier are taken in one beaker and melted in a water bath at $75^{\circ} \mathrm{C}$. And in other beaker water, preservatives and watersoluble components are taken and melted at $75^{\circ} \mathrm{C}$. After heating, the oil phase was taken in a mortar and pestle and slowly the water phase was added and triturated till clicking sound was heard. Finally, when the temperature cools down, perfuming agents and/or preservatives are added. In this preparation, water content will be more than the oil.

\section{- Preparation of $w / o$ emulsion creams}

The oil soluble components and the emulsifier are taken in one beaker and melted at $75^{\circ} \mathrm{C}$. And in another beaker water and water soluble components are taken and melted at $75^{\circ} \mathrm{C}$ After melting, water phase are taken in mortar and pestle and slowly oil phase was added and triturated till clicking sound was heard. And when the temperature of the cream will get cooled, then the perfuming agent are added. In this preparation, water phase will be less and oil phase will be more.[64]

\section{EVALUATION PARAMETERS OF CREAMS:}

1. Determination of $\mathbf{p H}$ : The $\mathrm{pH}$ of the cream can be measured on a standard digital $\mathrm{pH}$ meter at room temperature by taking adequate amount of the formulation diluted with a suitable solvent in a suitable beaker.

2. Physical appearance: The physical appearance of the cream can be observed by its colour, roughness and graded.

3. Spreadability: Adequate amount of sample is taken between two glass slides and a weight of $100 \mathrm{gm}$ is applied on the slides for 5 minutes. Spreadability can be expressed as,

$\mathrm{S}=\mathrm{m} * \mathrm{l} / \mathrm{t}$

Where, $\mathrm{m}=$ weight applied to upper slide.

$\mathrm{l}=$ length moved on the glass slide.

$\mathrm{t}=$ time taken.

4. Saponification value: $2 \mathrm{gm}$ of substance refluxed with $25 \mathrm{ml}$ of $0.5 \mathrm{~N}$ alcoholic $\mathrm{KOH}$ for $30 \mathrm{~min}$, to this $1 \mathrm{ml}$ of phenolphthalein added and titrated immediately, with $0.5 \mathrm{~N} \mathrm{HCl}$, note the reading as ' $a$ '. Repeat the operation omitting the substance being examined. Note the reading as ' $b$ '.

Saponification value $=(\mathrm{b}-\mathrm{a}) * 28.05 / \mathrm{w}$

Where,

$\mathrm{w}=$ weight of substance in gram.

5. Acid value: $10 \mathrm{gm}$ of substance is dissolved in accurately weighed $50 \mathrm{ml}$ mixture of equal volume of alcohol and solvent ether, the flask was connected to reflux condenser and slowly heated, until sample was dissolved completely, to this $1 \mathrm{ml}$ of phenolphthalein added and titrated with $0.1 \mathrm{~N} \mathrm{NaOH}$, until faintly pink colour appears after shaking for 30 seconds. Acid value $=n^{*} 5.61 / \mathrm{w}$

Where,

$\mathrm{n}=$ the no. of $\mathrm{ml}$ of $0.1 \mathrm{~N} \mathrm{KOH}$ solution.

$\mathrm{w}=$ the weight of substance in gram.

6. Viscosity: Viscosity of formulated creams can be determined by using Brookfield Viscometer

7. Homogeneity: The formulation was tested for the homogeneity by visual appearance and by touch.

8. Removal: The ease of removal of the creams applied was examined by washing the applied part with tap water.

9. Dye test: The scarlet dye is mixed with the cream. Place a drop of cream in a slide and cover with a cover slip and examine it under a microscope. If the disperse globule appears red and the ground colourless then it is $o / w$ type and the reverse condition appears in $w / o$ type of creams.

10. After feel: Emolliency, slipperiness and amount of residue left after the application of fixed amount of cream was checked.

11. Type of smear: After application of cream, the type of film or smear formed on the skin were checked.

12. Irritancy study: Mark an area of 1 sq.cm on the left hand dorsal surface. The cream was applied to the specified area and time was noted. Irritancy, erythema, edema was checked, if any, for regular intervals upto $24 \mathrm{hrs}$ and reported. 
13. Accelerated Stability Study: Accelerated stability study is conducted for formulation according to ICH guidelines.[65]

\section{CONCLUSION}

Creams are semisolid formulations widely acceptable by the society. The skin is the most accessible part of the body and as such is also highly vulnerable to injuries. In case of cuts, burns and wounds, topical formulations such as creams are the most preferred for treatment. Research and development for the formulation of pharmaceutical creams for wound healing purpose has grown in recent decades owing to its obvious benefits. With the progress in the pharmaceutical field and industry, it is assured that pharmaceutical creams will still be an interesting and appealing area of research for years to come. More advanced technologies and methods will be used for preparation, formulation and evaluation of creams in coming years. The demand of herbal constituents based creams are also increased day by day.

\section{ACKNOWLEDGEMENT}

Authors are highly thankful to Dr. Tilak Raj Bhardwaj, Dean of School of Pharmacy and Emerging Sciences for their support and encouragement and Department of Pharmacy, Baddi University for providing library facility during literature survey.

\section{REFERENCES}

1. Shah RN, Methal BM, A Hand book of Cosmetics Page No.1

2. Myers D, Surfactant Science and Technology, VCH Publishers: 1992, Pp. 209-247

3. Sahu T, Patel T, Sahu S, Gidwani B, "Skin Cream as Topical Drug Delivery System: A Review” Journal of Pharmaceutical and Biological Sciences, Published by Atom and Cell Publishers, ISSN: 2320-1924

4. James WD, Berger TG, and Elston DM, Andrews' Diseases of the Skin: Clinical Dermatology. (10th ed.) 2006, Philadelphia; Elsevier Saunders: 2006, p. 1.

5. Ross and Wilson. Anatomy and Physiology in Health and Illness, $11 \mathrm{e}$

6. Ansel HC, Popovich NG, Allen LV. Pharmaceutical dosage forms and drug delivery systems. Lippincott Williams \& Wilkins; 1995.

7. Rai R, Poudyl AP, Das S, Pharmaceutical Creams and their use in wound healing: A Review, Journal of Drug Delivery and

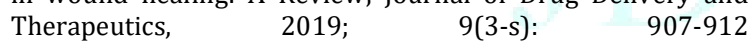
http://dx.doi.org/10.22270/jddt.v9i3-s.3042

8. Sahu T, Patel T, Sahu S, Gidwani B, "Skin cream as Topical Drug Delivery System: A Review" Journal of Pharmaceutical and Biological Sciences, 2016; 4(5):149-154

9. Mohiuddin AK, "Skin Care Creams: Formulation and Use" American Journal of Dermatological Research and Reviews, 2019, 2:8

10. Chapter 11. Semi-solid dosage forms. In: Alekha Dash, Somnath Singh, Justin Tolman. Pharmaceutics: Basic Principles and Application to Pharmacy Practice, published by Academic Press, 2013 ISBN 0123868912, 9780123868916

11. Swarbrick J, Rubino JT, Rubino OP. Chapter 22. Coarse Dispersions. In: Remington: The Science and Practice of Pharmacy Volume 1, edited by David B. Troy, Paul Beringer, published by Lippincott Williams \& Wilkins, 2006 ISBN 0781746736, 9780781746731

12. Jamshiya S, "Formulation and Evaluation of Herbal Skin Cream for Wound Healing" (Doctoral dissertation, RVS College of Pharmaceutical Sciences, Coimbatore

13. Rani S, Singh N ,Gautam SP, "Formulation, Evaluation Optimization and Evaluation of Dendricream for wound healing activity of Artemisia Indica" World journal of pharmacy and pharmaceutical sciences, 2016; 5(8):14831497.

14. Esimone CO, Ibezim EC, Chah KF, "Factors affecting wound healing" Journal of Pharma Allied Sciences, 2005; (1):294-299.
15. Avinash G, Priyanka B, "Wound healing potential of Indian medicinal plants" International Journal of Pharmacy Review \& Res, 2013; 2:75-87.

16. Pal A, Soni M, Patidar K, "Formulation and evaluation of polyherbal cream" International Journal Pharmaceutical and Biological Archives, 2014; 5:67-71.

17. Patel RP, KamaniR, "Formulation Optimization and Evaluation of Mometazone Furoate Cream" Journal of Pharmacy Research, 2009; 10:1565-1569.

18. Aswal A, Kalra M, Rout A, "Preparation and evaluation of polyherbal cosmetic cream" Der Pharmacia Lettre, 2013; $5(1): 838$

19. Sherrow V, "For Appearance' Sake: The Historical Encyclopedia of Good Looks" Beauty, and Grooming, 1995; 4:238-39.

20. Jamshiya S, "Formulation and Evaluation of Herbal Skin Cream for Wound Healing" (Doctoral dissertation, RVS College of Pharmaceutical Sciences, Coimbatore).

21. Avinash G, Priyanka B, "Wound healing potential of Indian medicinal plants" International Journal of Pharmacy Review \& Res, 2013;2:75-87.

22. Mittal A, Sardana S, "Herbal boon for wounds" International Journal of Pharmacy and Pharmaceutical Sciences, 2013; 5:112

23. Tiwari VK, "Burn wound: How it differs from other wounds?" Indian journal of plastic surgery: official publication of the Association of Plastic Surgeons of India. 2012 May; 45(2):364.

24. Sarabahi S, Tiwari VK, "Principles and practice of wound care' JP Medical Ltd; 2012 May 15.

25. Kiran K, Asad M, "Wound healing activity of Sesamum indicum $\mathrm{L}$ seed and oil in rats"

26. James OM, Victoria IA, "Excision and incision wound healing potential of Saba florida (Benth) leaf extract in Rattusnovergicus" Inter J Pharm Biomed Res, 2010; 1(4):1017

27. Saini S, Dhiman A, Nanda S, "Traditional Indian medicinal plants with potential wound healing activity: a review" International Journal of Pharmaceutical Sciences and Research, 2016; 7(5):1809

28. DiPietro LA, Burns AL, editors. Wound healing: methods and protocols. Springer Science \& Business Media; 2003

29. Builders PF, Kabele-Toge B, Builders M, Chindo BA, Anwunobi PA, Isimi YC, "Wound healing potential of formulated extract from hibiscus sabdariffa calyx" Indian journal of pharmaceutical sciences, 2013; 75(1):45.

30. Biswas TK, Mukherjee B, "Plant medicines of Indian origin for wound healing activity: a review" The international journal of lower extremity wounds, 2003; 2(1):25-39.

31. Prasad V, Dorle AK, "Evaluation of ghee based formulation for wound healing activity" Journal of ethnopharmacology, 2006; 107(1):38-47.

32. Duke JA. Handbook of medicinal herbs. CRC press; 2002 Jun 27.

33. Govindarajan R, Vijayakumar M, Rao CV, Shirwaikar AN, Mehrotra S, Pushpangadan P, "Healing potential of Anogeissuslatifolia for dermal wounds in rats" Acta Pharm. 2004; 54(4):331-8

34. Kulkarni PH, "The Encyclopedia of Ayurveda" Sri Satguru publication, 2005; 1:288-9.

35. Oryan A, Mohammadalipour A, Moshiri A, Tabandeh MR, "Topical application of Aloe vera accelerated wound healing, modeling, and remodeling: an experimental study" Annals of plastic surgery, 2016; 77(1):37-46

36. Herro E, Jacob SE. Menthapiperita (peppermint). Dermatitis. 2010; 21(6):327-9.

37. Modarresi M, Farahpour MR, Baradaran B, "Topical application of Menthapiperita essential oil accelerates wound healing in infected mice model" Inflammopharmacology, 2018: 6:1-7.

38. Saidi M, Aouacheri O, Saka S, "Protective Effect of Curcuma Against Chromium Hepatotoxicity in Rats" Phytothérapie. 2019.

39. Luthra PM, Singh R, Chandra R. Therapeutic uses ofCurcuma longa (turmeric). Indian Journal of Clinical Biochemistry. 2001; 16(2):153-60

40. Shetty S, Udupa SL, Udupa AL, Vollala VR, "Wound healing activities of Bark Extract of Jatrophacurcas Linn in albino rats" Saudi Medical Journal, 2006; 27(10):1473-6 
41. Bodeker G, Ryan T, Ong CK, "Traditional approaches to wound healing. Clinics in dermatology" 1999; 17(1):93-8.

42. Kwakman PH, Zaat SA, "Antibacterial components of honey" IUBMB life. 2012; 64(1):48-55

43. Parente LM, Júnior L, de Souza R, Tresvenzol LM, Vinaud MC, de Paula JR, Paulo NM, "Wound healing and anti-inflammatory effect in animal models of Calendula officinalis L. growing in Brazil" Evidence-based complementary and alternative medicine, 2012;

44. Preethi KC, Kuttan R, "Wound healing activity of flower extract of Calendula offlcinalis" Journal of basic and clinical physiology and pharmacology, 2009; 20(1):73-80

45. Prasad V, Dorle AK, "Evaluation of ghee based formulation for wound healing activity" Journal of ethnopharmacology, 2006; 107(1):38-47

46. World Health Organization. General guidelines for methodologies on research and evaluation of traditional medicine. Geneva: World Health Organization; 2000

47. Inpanya P, Faikrua A, Ounaroon A. Sittichokechaiwut A, and Viyoch J, Effects of the blended fibroin/aloe gel film on wound healing in streptozotocin-induced diabetic rats. Biomed Mater. 2012; 7:035008.

48. Tarameshloo M, Norouzian M, Zarein-Dolab S, Dadpay M, Mohsenifar J, and Gazor R, "Aloe vera gel and thyroid hormone cream may improve wound healing in Wistar rats" Anat Cell Biol, 2012; 45:170.

49. Atiba A, Nishimura M, Kakinuma S, Hiraoka T, Goryo M, Shimada $Y$, Ueno $H$, and UzukaY, "Aloevera oral administration accelerates acute radiation-delayed wound healing by stimulating transforming growth factor-b and fibroblast growth factor production' Am J Surg, 2011; 201:809.

50. Eshghi F, Hosseinimehr SJ, Rahmani N, Khademloo M, Norozi MS, and Hojati O, "Effects of Aloe vera cream on posthemorrhoidectomy pain and wound healing: results of a randomized, blind, placebo-control study" J Altern Complement Med, 2010; 16:647.

51. Takzare N, Hosseini MJ, Hasanzadeh G, Mortazavi H, Takzare $A$, and Habibi P, "Influence of Aloe vera gel on dermal wound healing process in rat" Toxicol Mech Methods, 2009: 19:73

52. Upadhyay NK, Kumar R, Mandotra SK, Meena RN, Siddiqui MS, Sawhney RC, and Gupta A, "Safety and healing efficacy of Sea buckthorn (Hippophaerhamnoides L.) seed oil on burn wounds in rats" Food Chem Toxicol, 2009; 47:1146.

53. Gupta A, Kumar R, Pal K, Singh V, Banerjee PK, and Sawhney $\mathrm{RC}$, "Influence of sea buckthorn (Hippophaerhamnoides L.) flavone on dermal wound healing in rats" Mol Cell Biochem, 2006; 290:193.

54. Hsiao C-Y, Hung C-Y, Tsai T-H, and Chak K-F, "A study of the wound healing mechanism of a traditional chinese medicine, Angelica sinensis, using a proteomic approach" Evid Based Complement Alternat Med, 2012: Article ID 467531.

55. Nayak BS, Pereira LMP, "Catharanthus roseus flower extract has wound-healing activity in Sprague Dawley rats" BMC Complement Alternat Med, 2006; 6:41.

56. Shenoy RR, Sudheendra AT, Nayak PG, Paul P, Kutty NG, and Rao CM, "Normal and delayed wound healing is improved by sesamol, an active constituent of Sesamum indicum (L.) in albino rats" J Ethnopharmacol, 2011; 133:608

57. Naeini AT, Miri R, Shafiei N, Tabandeh MR, Oryan A, and Nazifi $\mathrm{S}$, "Effects of topical application of Calendula officinalis gel on collagen and hydroxyproline content of skin in rats" Comp Clin Pathol, 2012; 21:253.

58. Parente LML, Ju 'nior RSL, Tresvenzol LMF, Vinaud MC, de Paula JR, and Paulo NM, "Wound healing and antiinflammatory effect in animal models of Calendula officinalis L. growing in Brazil" Evid Based Complement Alternat Med, 2012: 375671

59. Fronza M, Heinzmann B, Hamburger M, Laufer S, and Merfort I, "Determination of the wound healing effect of Calendula extracts using the scratch assay with 3T3 fibroblasts" J Ethnopharmacol, 2009; 10: 126.

60. Tiwari PC, Noor MA, Chand PK, Nagar K, Comparative Study of Wound Healing Activity of Soframycin and Honey in Excision Wound Model. National Library of Medicine, Pubmed. 2013.

61. Teran CG, Sura S, Cabandugama P, Berson C, "Silver nitrate ingestion: report of a case with an uneventful course and review of the literature" Clinics and practice, 2011; 1(3)

62. Maghsoudi H, Monshizadeh S, Mesgari M, "A comparative study of the burn wound healing properties of saline-soaked dressing and silver sulfadiazine in rats" Indian Journal of Surgery, 2011; 73(1):24-7

63. Bigliardi PL, Alsagoff SA, El-Kafrawi HY, Pyon JK, Wa CT, Villa MA, "Povidone iodine in wound healing: A review of current concepts and practices" International Journal of Surgery, 2017; 44:260-8.

64. Pal A, Soni M, Patidar K, "Formulation and evaluation of polyherbal cream" International Journal Pharmaceutical and Biological Archives, 2014; 5: 67-71

65. Aswal A, Kalra M, Rout A, "Preparation and evaluation of polyherbal cosmetic cream" Der Pharmacia Lettre, 2013; 5(1):838. 